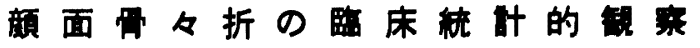

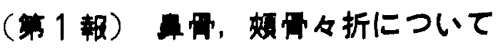

\author{
上野 正" ・岡達" ・金田敏 郎 \\ 風閒正守*・坂村吉保”・菌塚 患* \\ 飯名暄 郎**
}

\section{1) いとぐち}

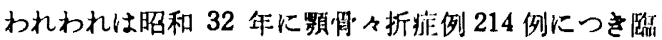
床珫計的観察を行ない報告した。これにそれ以後昭和 37 年 7 月 31 日迄の新症例を加えると胃，烦骨ならびに 頻骨を含めた顔面骨々折症例は 519 例に達した。このた びこれら症例につき臨床統計的钼察を行なつたので，第 1 報として骨，煩骨怙よびそれらと顎骨との合併骨折 33 例につき報告する。

われわれがここで規定した類骨々折には解剖学的の 煩骨以外の骨の骨折も含んでいる，すなわち，烦骨は正 中部は眼窝の下底, 上額洞の前方と側壁を, 側方は側頭 骨の煩骨突起と，上方は前頭骨と，後方は蝶形骨の大翼 と，それぞれ稌合線で結合している，そのために隣接骨 の骨折を合併する場合が多く，特に始骨弓骨折は犆骨の 側頭突起と側頭骨の煩骨突起の両骨々折を含む場合が多 い. 従つてわれわれは従来の概念にとらわれることなく 臨床症状を加味して分類することが最適と考え, 煩骨自 体の他に側頭骨の頓骨实起をむ併せて㛲骨弓骨折として 観察した.

\section{2）観 察対象}

観察対象:士昭和 6 年 4 月上り昭和 37 年 7 月 31 日ま でに東京医科歯科大学口腔外科を訪れた骨折患者 519 例 につき，外賃用プロトコールに記載された所見，ならび にX線フィルムに基ついたものである．X線フィルムは Tillesing 法, Waters 法を主体とし，特に煩骨々折の 場合は立体撮影法によるフィルムに重点を置き骨片偏位 を観察した。

われわれの症例では表 1 のごとく㑭，媔骨の単独骨 折は少なくそれぞれ 4 例，8例で，他の 21 例はいつうれ も額骨々折を合併したものであつたが，併わせて観察対 象とした。

\section{3）統計的観察成樍}

i) 骨折部位

骨折部位は表 1 のごとく，鼻骨と煩骨の単独骨折汹 4

* 東京医科歯科大学口腔外科学教室

** 陸上自停隊御生学校

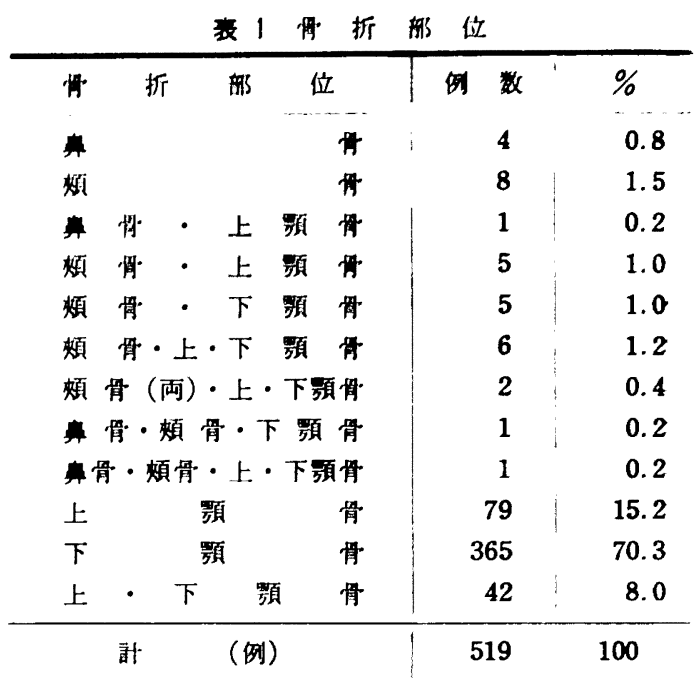

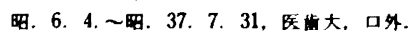

表 2 性别および年令別

\begin{tabular}{r|r|cc} 
& 男 & 女 & 計(例) \\
\hline $0 \sim 9$ & $\sim$ & & 1 \\
$10 \sim 19$ & 9 & & 9 \\
$20 \sim 29$ & 9 & 1 & 10 \\
$30 \sim 39$ & 9 & 1 & 10 \\
$40 \sim 49$ & 2 & & 2 \\
$50 \sim 59$ & & & \\
$60 \sim 69$ & 1 & & 1 \\
70 以上 & & & \\
\hline$\%$ (例) & 31 & 2 & 33 \\
\% & 93.9 & 6.1 & 100
\end{tabular}

例 $(0.8 \%)$ および 8 例 (1.5\%) であり，他の 21 例は すへて額骨々折を合併したものであつた。 このうち煩骨 々折に上頻骨，下額骨，上・下額骨々折を合併したもの か 16 例 (3.2\%) であつた.

ii）性別およひ年令別

性別（表 2)をみると，他の外賃にみられると同様男 性が圧倒的に多く，女性との比率は $15.5: 1$ (全症例で は $5.9: 1)$ であつた. 年令別では 20 才〜30才台の青 
壮年が多く，20 例 $(60.6 \%)$ で過半数以.たを占めてい た.また 9 才以下の 1 例は 5 才の小光で，道路偳断步行

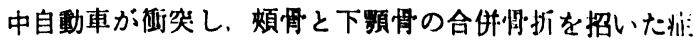

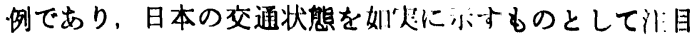
に值する.

\section{iii）受侮原因別}

骨折原因（表 3）についてみると交近忆故によるもの が過半数の $54.6 \%$ を占め，ついで俳莱标 (33.1\%). スポーッ事故（6.1\%）の順であつた，各小故原因につ

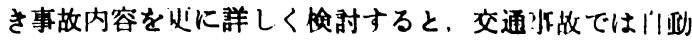

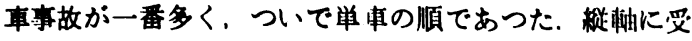
份者の受伤時状態を，横虫に事故の原因内容を記すと， 自動車と自助車の便突が多く，座席に微突した 2 例以外 の症例はすへてて自分で車を運忶していたものであつた． また歩行中自軖車，または単忙に衡笑されたものが 3 例 あつた。

表 3 骨折原 因

\begin{tabular}{|c|c|c|c|c|c|c|}
\hline 骨折部位 & $\begin{array}{l}\text { 交通 } \\
\text { 年故 }\end{array}$ & 作業 & $\begin{array}{l}\text { スポ } \\
\text {-ま } \\
\text { 年故 }\end{array}$ & 枟侄 & 俩突 & （例） \\
\hline 骨 & 3 & & & 1 & & 4 \\
\hline 煩 & 5 & 1 & 2 & & & 8 \\
\hline 鼻 骨 - 上 額 骨 & 1 & i & & & & 1 \\
\hline 煩 骨 - 上 額 骨 & 4 & 1 & & & & 5 \\
\hline 煩 骨 - 下 額 骨 & 3 & 2 & & & & 5 \\
\hline 煩 骨・上・下類 骨 & 1 & 4 & & & 1 & 6 \\
\hline 煩骨(両) - 上・下類骨 & & 2 & & & & 2 \\
\hline 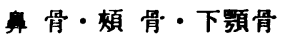 & 1 & & & & & 1 \\
\hline 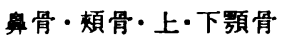 & & 1 & & & & 1 \\
\hline 計（例） & 18 & 11 & 6.1 & $\begin{array}{l}1 \\
3.0\end{array}$ & $\begin{array}{l}1 \\
3.0\end{array}$ & $\begin{array}{r}33 \\
100\end{array}$ \\
\hline
\end{tabular}

表 4 交通事故原因

\begin{tabular}{|c|c|c|c|c|c|c|c|c|}
\hline 原因 & & 衝 & & 突 & & 車 & & \\
\hline 倪 & 自動車 & 単車 & 自転車 & 座席 & 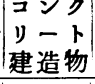 & $\begin{array}{l}\text { 転 } \\
\text { 落 }\end{array}$ & 坛任 & 解 \\
\hline 自動車 & 4 & & & 2 & & 1 & & 7 \\
\hline 単 車 & 1 & & 1 & & 1 & 1 & 2 & 6 \\
\hline 自転車 & 1 & & & & & 1 & & 2 \\
\hline 歩行中 & 2 & 1 & & & & & & 3 \\
\hline 計 & 8 & 1 & 1 & 2 & 1 & 3 & 2 & 18 \\
\hline
\end{tabular}

表 5 作業事故

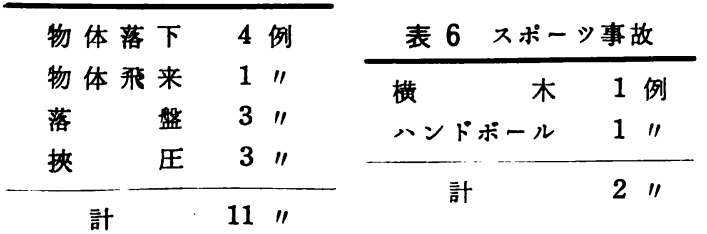

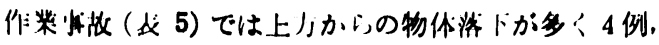

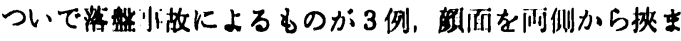
れた挟压が 3 例むつた。

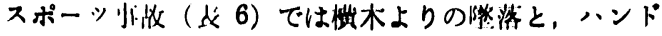
ボール武们他人の伴と洒笑したものが各 1 例あつた。

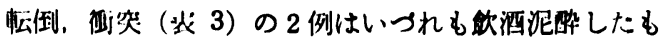

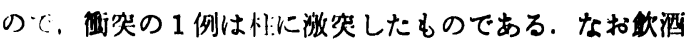

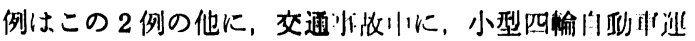

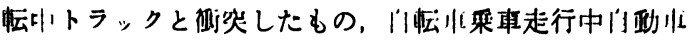
に揬触し忶侀した 2 例がむつた。

\section{iv）折の程度}

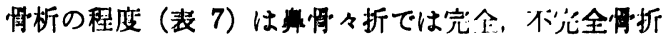
がほほ同数あり，烦悀々折では完全解折が圧倒的に多く 20 例にみられた。 な和外力の作用状態は留骨，煩置々 折ともすへてて直達によるものと推定された.

不完全骨折 10 例の内訳をみると，側頭骨の煩骨突起 へかけての徸裂骨折が 1 例，屈曲骨折は，煩骨に 7 例と 县骨に 2 例みとめられた。

表 7 骨折 の 程 度

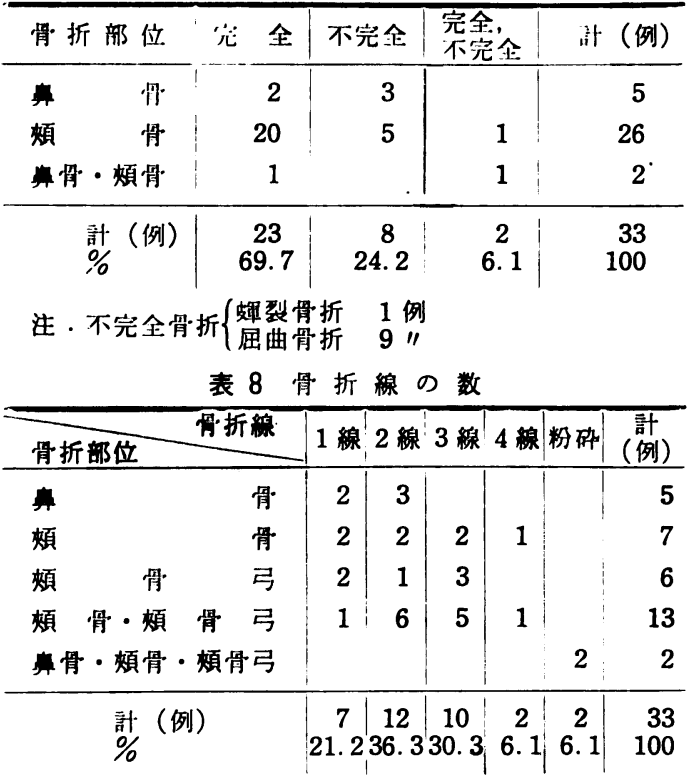

\section{v）骨折線の数}

骨折線の数（表 8) についてみると，自骨，煩骨とも 単骨折は少なく，2線，3線のものが多く $66.6 \%$ であ つた.

\section{vi) 左 右 別}

左右別では（表 9) 興骨折は片側性 3 例(左側 2 例, 右側 1 例)，両側性 4 例でその差はなかつた. 煩骨々折 は図 1 の骨折線図に示すごとく, 左側が過半数（17 例） を占め，ついで右側，両側にわたるものであつた．煩骨 の骨折部位は, 煩骨前頭縫合部, 煩骨上䫑程合部, 煩骨 側頭繶合部の骨折が多くみられた.ただ煩骨前頭繾合部 
衰 9 左在别

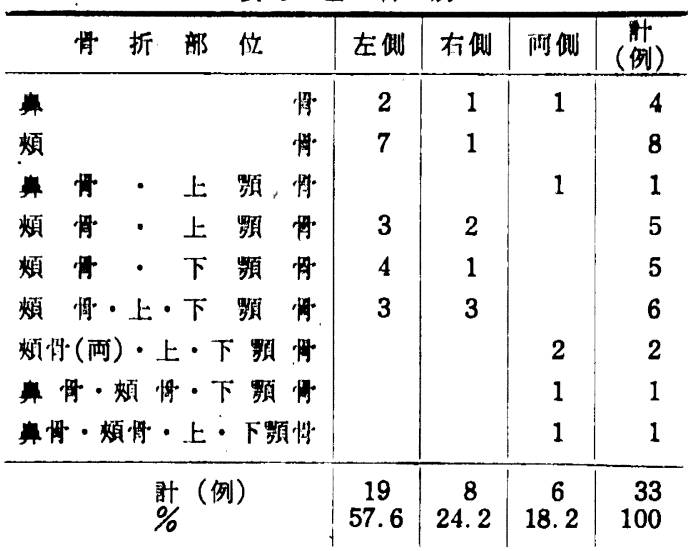

の骨折は右側では1 例にしか認められなかつた。

vii）受第時出血部位と失神の有無

受修時の出血部位（表 10）では，合併䫫骨䯚折のた

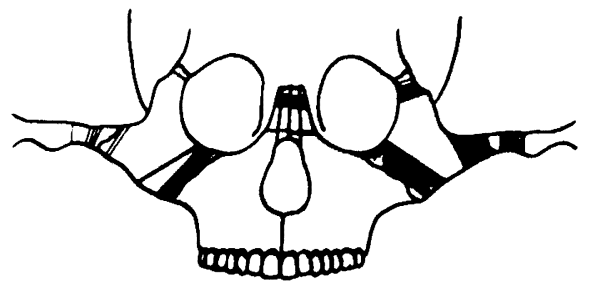

因 1 折搝必

めもあるが，口腔からの出血が過半数の 20 例にみられ。

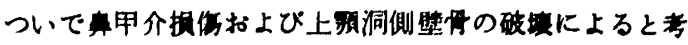

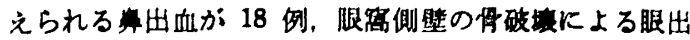
血が 9 例にみとめられた。失神は 22 例 $(66.7 \%)$ Kみ られ，短いるので数分から，曼期のるので 18 日繶行し たものがあり，意識消失のなかつたものは８殊に通さな い.いつれむ折の重庭のものほとその時間は延展する

表 10 出血部位と失神

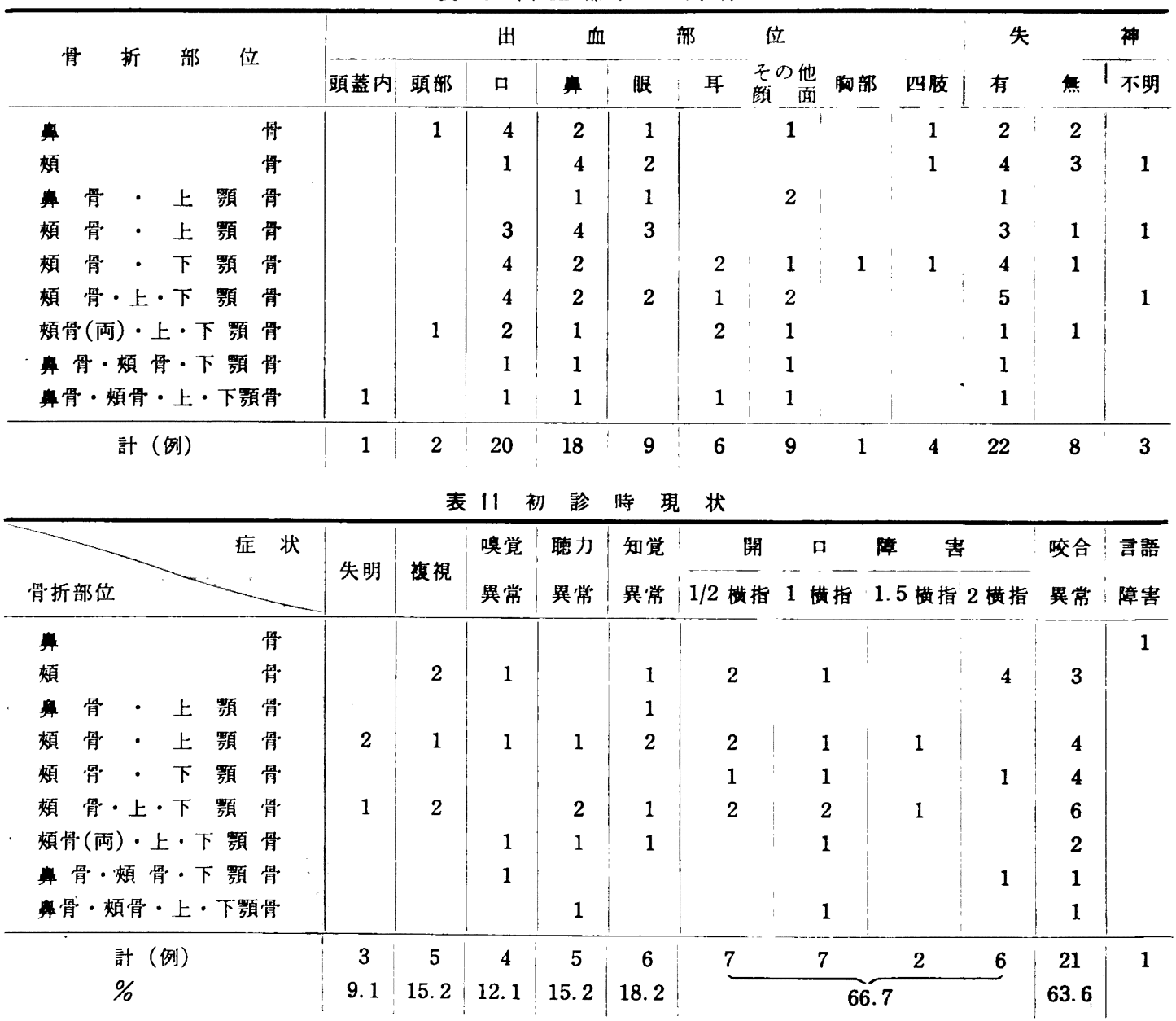


衰 12 剑扑你

\begin{tabular}{|c|c|c|c|c|c|c|c|c|c|c|c|c|c|c|c|}
\hline 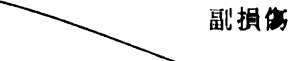 & 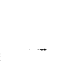 & 軟 & 垶 & & 田 & 仿 & & 小 & if & 折 & & & & 掑伤 & 不朋 \\
\hline 骨折部位 & 顽部 & 袥面 & 顒部 & 舌 & 胸部 & 腰部 & 四肢 & 设部 & 版部 & 期部 & 四肢 & 犾節 & 购椎: & 胍し & \\
\hline 臭 & 1 & 4 & & 1 & & & 2 & & & & & & & & \\
\hline 頉 & & 4 & 1 & & & 1 & 2 & & 1 & & 1 & & 1 & 3 & \\
\hline 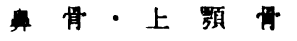 & & 1 & & & & & 1 & & & & & & & & \\
\hline 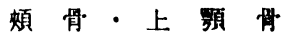 & 1 & 5 & & & & & & & & & 1 & & & & \\
\hline 䅡 骨 - 下額 骨 & 1 & 3 & & & 1 & & 1 & & 2 & & & 1 & & & \\
\hline 煩 骨・上・下顆 骶 & 2 & 1 & & & 1 & & 1 & & 1 & 1 & & 1 & & & 1 \\
\hline 煩骨(両) -上下・影颔 & 2 & 2 & & & & & & 1 & & & & & & & \\
\hline 骨・㛲骨・下額虫 & & 1 & & & & & & & & & & & & & \\
\hline 情・煩骨・上・下顎骨 & 1 & 1 & & & & 1 & 1 & & 1 & 1 & 1 & & & & \\
\hline 計（例） & 8 & 25 & 1 & 1 & 2 & 2 & 8 & 1 & 5 & 2 & 3 & 2 & 1 & 3 & 1 \\
\hline
\end{tabular}

傾向にあつた。特に 18 日間意識の消失をみた 1 例は単 車に乗車し，運転を誤り道路より $200 \mathrm{~m}$ の崖下に墜落 したもので，右煩骨々折，上額骨々折（Le Fort I， II 型骨折）に右暁骨および尺骨々折を合併したものであつ た。

\section{viii）初診時現症}

初診時現症（表 11）では，眼窝側壁および下底の骨 破壊に基つくく考えられる失明が 3 例，複視が 5 例にみ られた。 また三叉神経賃害による同領域の知覚異常が 6 例に認められた。開口障害は $1 / 2$ 横指程度より 2 横指ま で 22 例 $(66.7 \%)$ にみられ，咬合異常は $63.6 \%$ に惹 起していた．特に開口障害は煩骨々折ではほとんどの症 例にみられた。 また覓骨々折にみられた言語障害は舌の 裂稘によるものであつた.

\section{ix）副 损 伤}

副損賃（表 12）はその大部分が身体各部に種々なる程 度の損伤を受け，これを認めなかつたものは煩骨単独骨 折の 3 例のみであつた，軟部損儌では顔面の裂創，挫賃 が多く，頭蓋骨，肋骨，坐骨四肢の合併骨折か; 11 例に みとめられた。 また額関節の脱臼が 2 例と, 胸椎脱臼が 1 例あつた。

x）骨折の時间的経過

骨折の時間的経過（表 13）をみると，受伤後 10 日以 内に来院した新鮮症例は 10 例に過ぎず，他の 23 例は

表 13 胃折の時間的経過

新鮮骨折 (10 日以内)
陳 旧性骨折 (10 日以上)

表 14 治療内 容

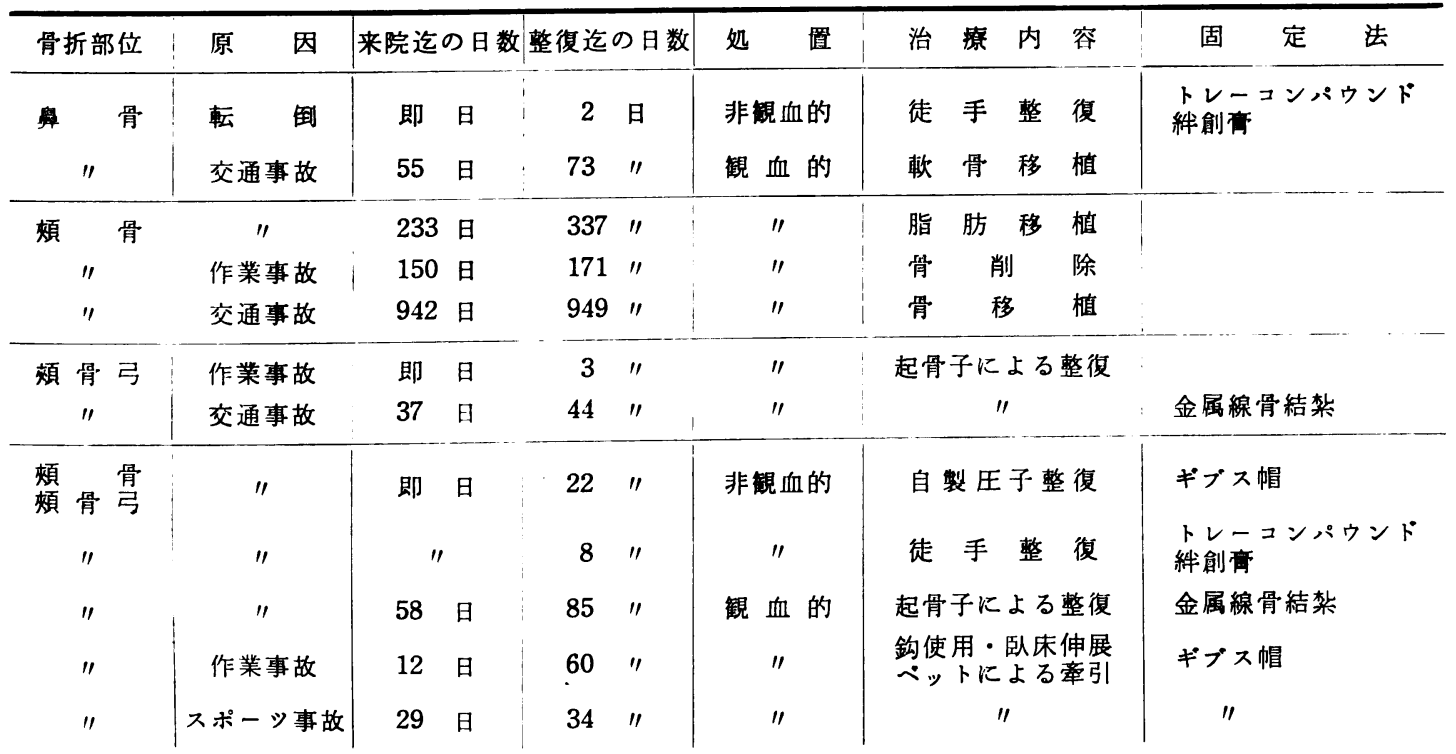




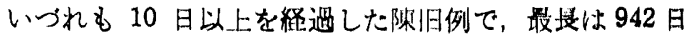
目に来院したむのがあつた。

\section{xi）処}

処㯰（表 14）之しては 33 例中 12 例に対し，来院の 時期により非钼血的むるいは钼血的処咸を行ない，他の

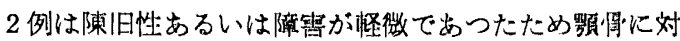
する処首のみに留めた。

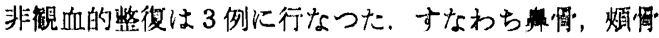
々折の各 1 例は徒手にて獘得し、トレーコンパウンドと 紏剩高にて固定した，受偖後瞥得までの日数はそれぞれ 2 日および8日であつた。また煩觖々折の他の1例は骨 折部が外方へ突出せるため，自憼ギブス国定帽より出し たPeloffe（压子）にて整得固定した。

観血的処置は畜骨々折 1 例，煩骨々折 8 例の部 9 例に 行なつた。すなわちその内訳は形成手術 4 例と，整復手 術 5 例である.

形成手術症例はいつれも受伤後長期間を経過している ため，顔貌の酲形を対象に行なつたものである。すなわ ち奥骨々折による陥山の 1 例に対しては肘軟骨移植を， 頓骨々折の陷没による酸形には 1 例に煩脂肪体移動を， 1 例に腸骨の添加骨移植を行なつた。 また頓骨々折で骨 折端が外方へ突出せる 1 例に対しては，咨出骨の削除手 術を施行した。

観血的整復手術は煩骨弓陥凹骨折 3 例，煩骨陷凹骨折 2 例の計 5 例について行なつた。すなわち煩骨弓の陥凹 骨折に対してはわれわれが顎関節援動手術に扣いて用い ている耳珠切開法により骨折部位に達し，起骨子にて整 復した．また煩骨の楩凹骨折 2 例に対しては陷山骨片に 歯科用コバルタム鈎を立て，臥床伸展ベットにて前外方 へ牽引整復し好結果を得た。

\section{4 総括考按}

鼻骨，欧骨々折で口腔外科を訪れるものは比較的少な い.これは合併損傷が重篤なため他科を受診したり，ま たこの部の単独骨折では単純骨折が多いため受傷時に見 落され, 後になり開口障害や隣接器官の機能障害のため 問題にされ来院するためと考えられる．煩骨々折の頻度 は Schoeubauer によると頭蓋骨 497 例中 143 例すな わち $28.8 \%$ ，Knightは 9 年間に㛲骨単独骨折 120 例 を報告し，欧米に括ける頻度はかなりの高率を示してい る. 本邦における報告は少ないが，古くは齐藤はスポー 外倁の 1426 例中, 奥骨々折は 10 例 $(0.7 \%)$, 煩骨 々折は 7 例 $(0.4 \%)$ であつたと報告し，尾崎は全身骨折 症例 1169 例中畽骨々折 12 例 $(1.0 \%)$ ，煩骨々折 7 例 $(0.5 \%)$ ，加藤は同しく 524 例中覺骨々折 2 例 $(0.4 \%)$ であつたという．大野は昭和 33 年 9 月から昭和 35 年 8 月までの顔面創傷患者 225 例中煩骨弓骨折の頻度は 6 例 $(2.3 \%)$ と報告している.われわれの症例では 519 例の顔面諸骨々折症例中奥骨, 頉骨々折は 33 例(6.3\%)

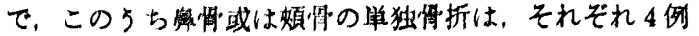
$(0.8 \%) ， 8$ 例 $(1.5 \%)$ であつた.

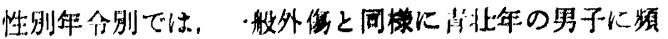
度が融かつた，特に 9 才以下の小尘にも見られたことは 欧米の統計と比呅して这目に做し，Knight む指摘して いることく，小贸では子後不良が多いため閴题になると

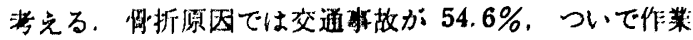

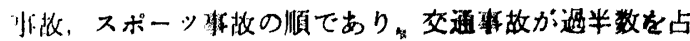

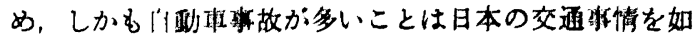
处にボしたものである。

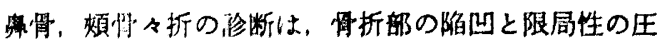

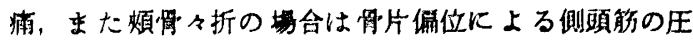

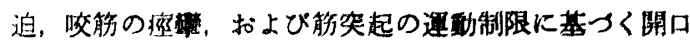
障管などがあげられている，この他腂脤，皮下血腫ある いは裂㑺部よりの出血など出血部位が颜断の禣助にな

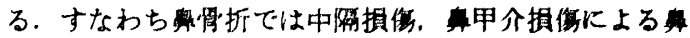
出血，また頉骨々折の場合は骨片偏位は内下後方でしか むこれに迴転転位が加わるため，眼億側壁を權成してい る前頭楔状突起，および上額突起の上半部骨の破壤によ る，眼窝内出血，眼球，眼球結膜下出血あるいは眼瞹皮 下出血など，ならびに上額洞の側壁と接合している上頻 突起下半分骨破壇による舅出血などである．われわれの 症例においても出出は 18 例，眼出血は 9 例に認めら れた。

舆骨および頓骨々折は外力の作用方向から考えると特 別の場合を除き内方へ压入楩没する場合が多い、したが つて徒手による整榎は困難とされているが，われわれは 新鮮奥骨々折 1 例扣よび，突出せる頝骨々折の 1 例に対 しては徒手整復を試み、トレーコンパウンドと䋖創高に よる固定にて好結果を得た。また陣旧與骨々折の場合は 顔貌の酸形以外に特別な機能障害が認められない場合 は，観血的整復よりはむしろ形成手術を行なつた方が好 成績を得るように思われる。頉骨々折の整復法には， Gillies, Böhler, Thoma, Mathews, Knight ら多くの 報告があるが，われわれは頓骨弓の陥没骨折 3 例には耳 珠切開法（上野）により骨折部へ達し，起骨子にて整復 し，また頓骨の陷没骨折 2 例に対しては卧床伸展べット による索引整復を行ない好結果を得た.

\section{5）結論}

昭和 6 年 4 月より昭和 37 年 7 月 31 日までに，東京 医科菌科大学口腔外科を訪れた顔面諸骨々折 519 例中,

奥骨，煩骨およびこれらと顎骨との合併骨折 33 例につ き㓍計的観察を行ない次の結論を得た。

i ) 悬骨 (4 例)，煩骨 (8 例) の単独骨折は少なく 顎骨との合併骨折（21 例）が多くみられた.

ii）性別では男性が多く，年令では 20 才〜30才台 が過半数を占めていた。

iii）原因では交通事故が多く，ついで作業事故，ス 
ポーシ事故の順であつた。

iv）骨折の程度は，围情へ折では完全、不完全がは ば同数あり，煩骨々折では完全骨折が圧倒的に多くみら れた。

v）骨折線の数は，単骨折は少なく，2線，3線のも のが多かつた.

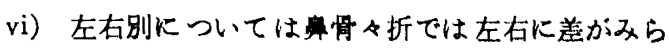
れなかつたが，煩骨っ折では左側が過半数を「やめていた。

vii）有折の時間的経過をみるとその大部分か：10日 以上を経過した陳旧例でむつた。

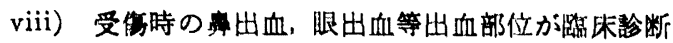
の補助になると考えられた。

ix）初診時現症では失明，被視、三叉种程領域知覚 異掌の他に，開口障紫は煩骨々折の殆んどの症例にみら れた.

x）副提倠は顔面の裂創，挫传が多く，また身体他 部の合併骨折が 11 例にみられた.

xi）処置としては非観血的整復術 3 例，形成手術 4 例，観血的整復手術 5 例の計 12 例に行ない好成績を得 た.

本諭文の要旨は昭和 37 年 10 月 20 日第 7 回口脖外 科学会棇会において発表した。

\section{文萳}

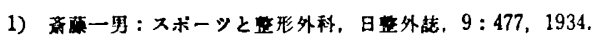

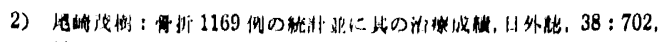
1937.

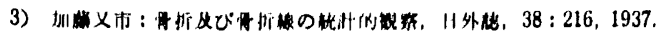

4) Reither, W. : Statiotioche Unterauchungen an Hand des Kleferbruch Krankengutes der Klinik für ZahnMund-und Kleferkrankhelten der Univeraltat München aus den Jahren 1945 blo 1953, Dtuch Zahnarztl. Z . H. $7: 384,1956$.

5) Knight, J.S. et al: The classiflcation of Malar Fractures: An Analyeis of Displacement as a guide to Treatment. Brit. J. Plast. Surg., $13: 325,1961$.

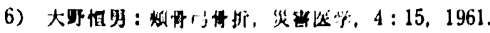

7) Schoenbauer, H. R. : Zur Behandlung der Jochbogenbrüche, Chirurg., $25:$ 404, 1954.

8) Gillies, H.D., et al. : Fractures of the malar-zygematic Compound: with a description of a new X-ray position, Brit. J. Surg. $14: 651,1927$.

9) Nesbitt, B. E. et al. : Fractures of the Zygomatic bone, Brit. med. J. 1:512, 1945.

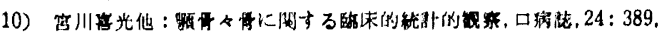
1957.

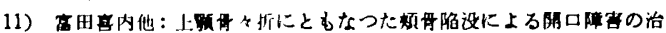

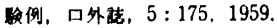

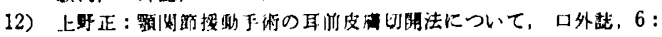
$206,1960$.

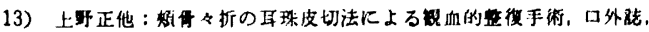
$7: 122,1961$.

14) Bingham, C.B. : The Fractured Malar. O.S.O.M.O. P., $8: 13,1955$.

15) Thoma, K. H. : Oral surg. 3 rd Ed., p. 467, 1958.

16) Archer, W. H. : Oral surg. 3 rd Ed., p. 790, 802, 1961. 